\title{
J.H. Pierneef and the Union Buildings
}

\author{
Alexander Duffey*
}

\begin{abstract}
* Alexander Duffey is Associate Professor in History of Art and Chief Curator of the University of Pretoria Heritage Collections.
\end{abstract}

\begin{abstract}
In 2010, the Union Buildings, one of the most important landmarks of Pretoria and certainly one of South Africa's finest buildings, are 100 years old. They were erected on Meintjeskop between 1910 and 1913. In more than 70 known artworks depicting Meintjeskop Hill and the construction of the Union Buildings, which he made between 1905 and 1948, the artist Jacob Hendrik Pierneef rejected the placement of these buildings on the well-known hill. Pierneef, who considered Meintjeskop to be an important landmark of old Republican Pretoria, regularly used it as subject matter for his experiments with a variety of artistic styles, in an attempt to find the most appropriate style with which to capture the typical atmosphere, light conditions and structural peculiarities of this well-known Pretoria landmark. This article attempts to show that Pierneef's lifelong obsession with Meintjeskop was not only a deliberate attempt to use the landmark to develop his own typical artistic style, but also to reflect his ideological stance with regard to the Union Buildings as a symbol of British Imperialism in South Africa.
\end{abstract}

\section{Introduction}

This article attempts to show that the lifelong obsession of the South African landscape artist, Jacob Hendrik Pierneef (1886-1957), with Meintjeskop (where the Union Buildings were built in 1910), was not only a deliberate attempt to use this Pretoria landmark to develop his typical artistic style, but also a means to voice his rejection of the placement of the buildings as a symbol of British Imperialism on the well-known hill. Pierneef did not want to accept the transformation that the erection of the Union Buildings would bring to Pretoria. Meintjeskop, nevertheless, contained most of the visual landscape elements with which Pierneef grappled during his early career in his attempts to find a characteristic artistic style - its typical South African trees, a prominent, recognisable hill, the meandering Apies River and the typical cloud formations of Pretoria. The 70 known artworks by the artist, representing Meintjeskop and the construction of the Union Buildings, clearly show Pierneef's experiments with a variety of artistic styles in his attempt to find a style which, in his view, best captured the atmosphere, light conditions and structural peculiarities of this well-known landmark.

About five kilometres east of Church Square in Pretoria there is a well-known pointed hill in the Daspoortrand to the north of the Apies River Valley that has been a select dwelling since very early times. According to tradition, the main kraal of the Matabele of Moselekatse (Mzilikazi) stood on this hill long before the arrival of the white man in this region (Potgieter 1953:5). Later, this hill was to acquire the name Meintjeskop. Initially referred to as 'Meintjies' Hill', already from 1870 onwards it became known as 'Meintjeskop' (Punt 1955:249) (1).

Meintjeskop forms part of the farm Elandspoort, a section of which became the property of Commandant-General Marthinus Wessel Pretorius, the founder of Pretoria and first President of the South African Republic. Andries Francois du Toit, a wandering tradesman, purchased a one-third portion of the eastern half of Elandspoort - that portion of the farm around the present Union Buildings - from one of the inheritors of the estate of J. Gerrit S. Bronkhorst, the original owner of the farm. Having visited the new township of Pretoria for the first time in 1856, Du Toit returned in 1857 to settle there, becoming Pretoria's first magistrate in May of the same year, and beginning the task of re-surveying the town. Du Toit sold his portion of Elandspoort (on the western and eastern banks of the Apies River), which he called Arcadia (and on which the hill was situated), to Stephanus Meintjes on 7 April 1865 (Andrews 1962:32). The hill was eventually named after said Meintjes whose son, Edward Philip Arnold Meintjes, later inherited the property and built a home on the slope below the hill. This farmstead was used as an internment camp for Boer prisonersof-war after the fall of Pretoria in 1900. The artist, Frans David Oerder (1867-1944) was interned here from 1901 to the end of 1902.

\section{The Union Buildings}

The Union Buildings, which can be regarded as the crowning achievement of Herbert Baker's career in South Africa, celebrate their 


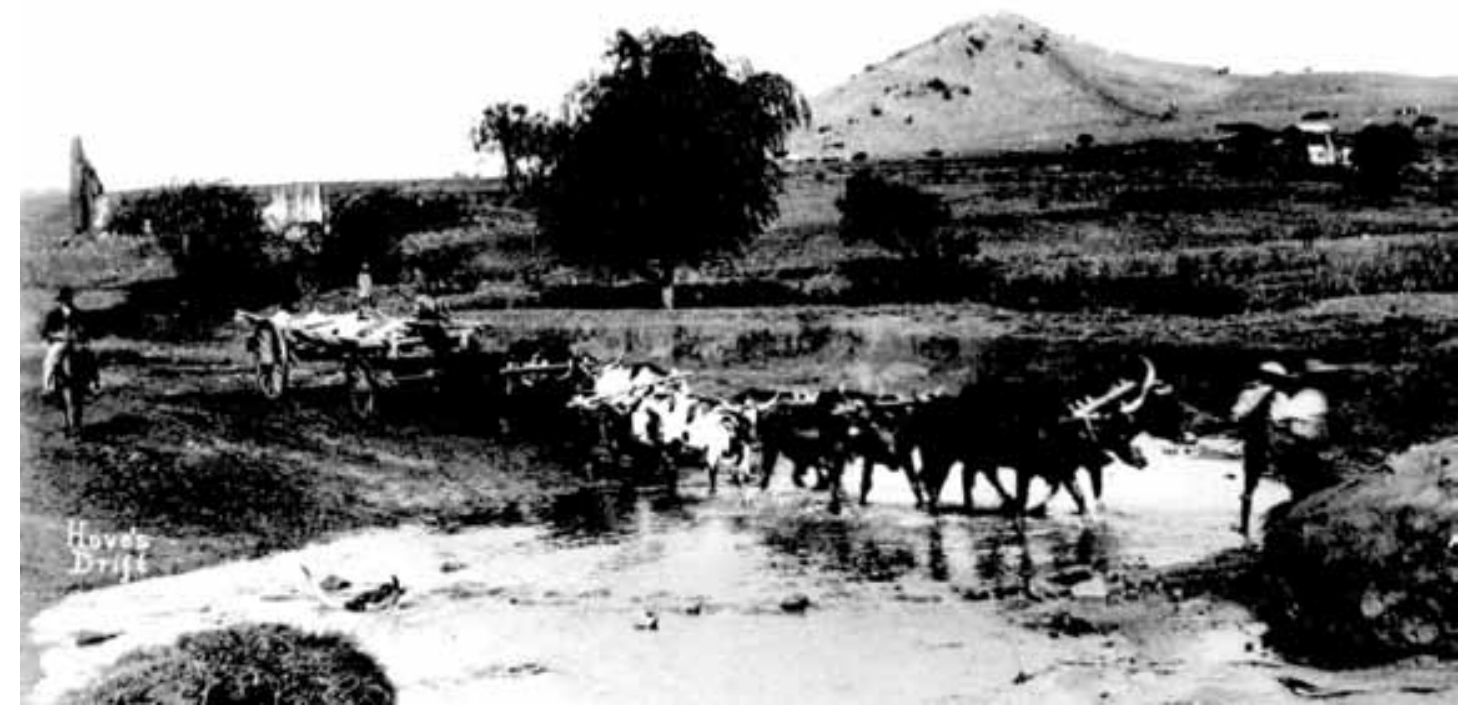

1 Photograph of Van der Hove's Drift in 1890. (National Archives Repository, Pretoria: SAB 1131). This drift in the Apies River was well known to Pierneef. Note the barren Meintjeskop hill in the background.

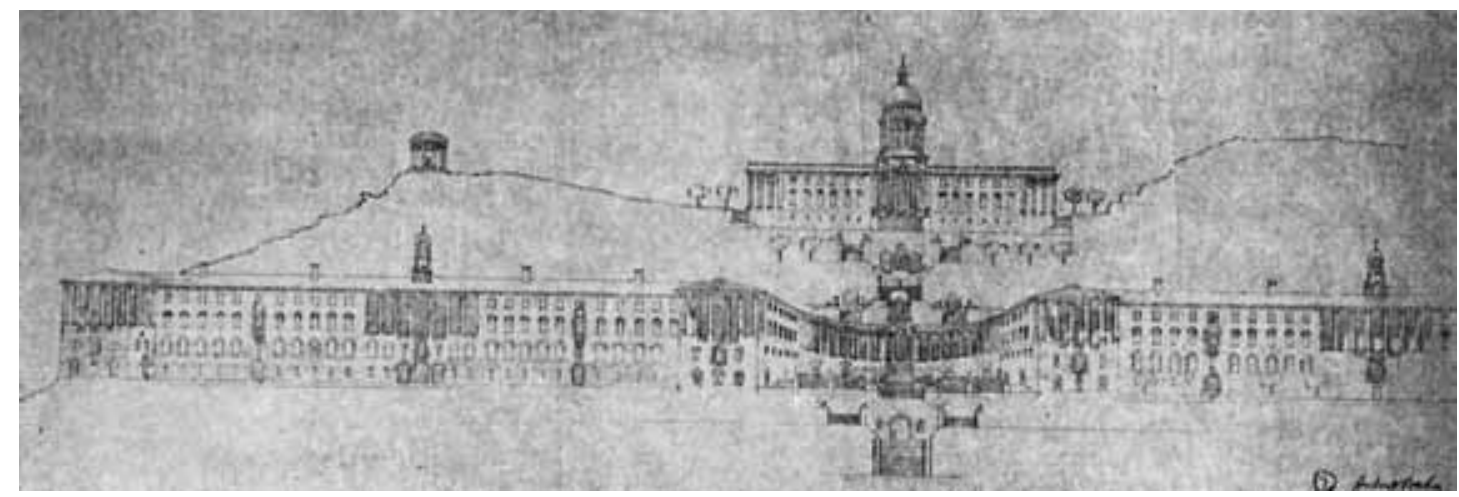

2 Herbert Baker, Perspective drawing of the Union Buildings showing the proposed parliament building on the hill behind the Union Buildings. (National Archives Repository, Pretoria: SAB 1834.)

centenary in 2010. They are one of the most important landmarks of Pretoria and certainly one of South Africa's finest buildings. With this evocative symbol of a new British-South African nationalism after the 1908-1909 National Convention in Durban, Baker intended to glorify the basic premise of union, namely of reconciliation between Boer and Briton, following the Anglo-Boer War. This reconciliation would be visually represented in the two identical office blocks connected by a semi-circular colonnaded building and amphitheatre. Christenson (1996:5) has convincingly shown that Baker's inclusion of a parliament building (on the hill behind the main office blocks in his original drawings for the Union Buildings) indicates that he was aware of the specific political agenda of the then Prime Minister, Louis Botha, and the then Colonial Secretary, Jan Smuts, to make Pretoria the sole capital of the Union after unification in 1910 (2). In a letter to Louis Botha, dated 26 June 1909, Baker outlined his ideas on Meintjeskop. ${ }^{1}$ In the face of opposition, Baker chose as his site the disused quarry between two flat shelves on Meintjeskop, east of the existing built areas of Pretoria. He used the quarry to form an amphitheatre, with its concave bow fronted with twin columns to form the link between two identical administrative buildings. It appears that the buildings were first envisaged as offices for the Transvaal Government only, but when the possibility of the union of the four colonies became a practical reality early in 1909 , the programme was amended to allow them to become the 
seat of the new National Administration (Radford 1988:62). Baker received official consent for his design on 24 November 1909, but drew a discreet veil over the precise date of his appointment, because he was aware that the Transvaal Cabinet had no legal right to commit the forthcoming Union Parliament to such expenditure (National Archives Repository, Pretoria: P.W.D. file 13/5267).

The Transvaal Legislative Council had decided that the surplus in its treasury, approximately $£ 1,5$ million, would be used for the construction of the new government buildings in the new executive capital, Pretoria. It was his ability to handle not only the design of the Pretoria station building, but also its contractual side, that made Baker the natural choice for the design of the contemplated Union Buildings (Baker 1944:57). ${ }^{2}$ Baker stuck to the unused quarry on the hill known as Meintjeskop as the site for the new building, and a year after he received the commission, the foundation stone was laid by the Duke of Connaught on 26 November 1910.

From the very beginning, Baker envisaged the Buildings as two blocks flanking a semicircular colonnade, where the wings are two stretched versions of the Pretoria station building, but with the ends terminated by porticoes. The two wings represented the two white groups in South Africa, Afrikaners and English (former enemies), while the amphitheatre represented peace, reconciliation and democracy. Ultimately, the design was in a modified Neo-Renaissance style, with two towers flanked by colonnades.

The contract for the Buildings was subdivided so that the central block - including the colonnades - was constructed by the builders Prentice \& Mackie, and the east and west blocks by the well-known Pretoria master builder, M.C.A. Meischke (1859-1935).

Baker made ample room for architectural decoration such as decorative keystones, heraldic figures with shields, freestone quoins and festoons on the walls and balconies of the Buildings in his designs, but because of the scope of the endeavour he could not leave it to a single sculptor to complete all the sculptural work, so he allowed the builders to subcontract the numerous stone sculptors and stone carvers needed. Amongst others, Meischke subcontracted the sculptor, Anton van Wouw, to do the designs for some of the leonine heads and emblematic figures for the fountains and exterior of the Buildings in 1910. It was through Meischke, an old friend of Pierneef's father, as well as through his godfather, Anton van Wouw, that Jacob Hendrik Pierneef acquired permission to enter the site where the Union Buildings were being built in 1910, to make his drawings.

\section{Jacob Hendrik Pierneef and Meintjeskop}

The South African painter, Pierneef, had a very long association with the hill known as Meintjeskop. It was always a familiar sight to the artist, because his home in De Waal Street was situated slightly to the north-west of the hill, in the vicinity of the present zoo. When he looked out of his front door he was greeted by the Apies River meandering towards this hill sloping gently in the distance. How the hill looked before the Union Buildings were erected, is captured in a pastel drawing at present in the Pretoria Art Museum, which Pierneef made in 1913 (15). The representation of this hill has always occupied a very prominent place in Pierneef's output: during the period 1905-1948 he made about 70 known drawings and paintings depicting the hill from different angles.

Already as a pupil at the Staatmodelschool before the Anglo-Boer War, Pierneef used to visit the area on Saturdays with his Natural Sciences teacher, Dr Herman Breyer, who required his pupils to collect rocks, plants and bones there (Transvaler 9 December 1944:3). When Pierneef returned to Pretoria after the Anglo-Boer War in 1903, he took drawing and painting lessons from Frans Oerder (18671944). Some of his very earliest existing drawings were made as Oerder's student at the so-called 'Donkiekamp' on Meintjeskop in $1905 .^{3}$ By 1908, aged 22, Pierneef felt he had accumulated enough skill as an artist to exhibit his work publicly. On 14 and 15 August of that year, he exhibited his paintings for the first time in a group exhibition in the Tudor building. ${ }^{4} \mathrm{He}$ exhibited a pencil drawing of the Donkiekamp (dated 1908), which is at present in MuseumAfrica (62/1573), at this exhibition. This was also the year in which Pierneef started work as assistant at the State Library, while boarding with the Delen family in Proes Street (Pretorius 1990:37).

After Pierneef's marriage to Agatha Delen on 16 February 1910, the young couple moved 
into a small house in De Waal Street, where the artist built himself a studio at the back of the house (De Volkstem 23 August 1912). It was from this base that he regularly walked all over Pretoria, to make sketches of the landscape and buildings (on his days off at the library) before using these sketches in the paintings he created in his studio.

The period from 1910 to October 1913, when he held his first solo exhibition in Pretoria, was one of much soul-searching and experimentation. Pierneef had access to many good books on art in the State Library and he met well-informed artists in Pretoria at this time, amongst whom were Eduard Frankfort (1864-1920), ${ }^{5}$ Pieter Wenning (1873-1921), George Smithard (1873-1919), ${ }^{7}$ Marcelle Piltan (?- 1938), ${ }^{8}$ Pieter Hugo-Naudé (1868-1941) and Erich Mayer (1876-1960), not to mention his tutors, Anton van Wouw (1862-1945) and Frans Oerder (1867-1944). Oerder, Frankfort and Smithard encouraged Pierneef to find a typical South African style, and made him aware of the peculiarities of the harsh South African sunlight. From Wenning he learnt to be true to himself and to trust his instincts (Pretorius 1990a:166). After Erich Mayer came to Pretoria in October 1912, he and Pierneef became close friends. Mayer not only discussed matters of artistic style with him, but also introduced Pierneef to the work of contemporary European modernists such as Ferdinand Hodler (1853-1918) and the Jugendstil which would show the way to Pierneef's new style. Mayer also made Pierneef aware of the importance of San rock art in developing his style. ${ }^{10}$ During this period Pierneef grappled with artistic issues - he accepted he was no figural painter, because he could not draw figures. He realised that formal proportions were not as important in landscape painting as they were in figural painting - certain liberties could be taken without disturbing the essential character of reality. ${ }^{11}$ In his landscapes he wanted to evoke an atmosphere that expressed the essence of the African landscape. In this regard, Kowie Marais (1964:3) aptly notes that 'Pierneef rarely painted from nature. The vast majority of his oils were studio products, done from a pencil sketch or a watercolour, or even purely from memory or fantasy.' Pierneef instinctively recognised the essential elements of the South African landscape - flat planes, pronounced linear rhythms and strong contrasts of light and dark. He found them in San rock art and in the simplification of the artists of the Monumental Decorative movement. When one takes the Meintjeskop/Union Buildings paintings as a whole, it becomes obvious that Pierneef believed that to achieve an aesthetic effect with his work, he had to manipulate the perceptual world both structurally and ideologically.

In light of the importance of Meintjeskop as a subject in the development of his oeuvre, it is significant that the very first oil painting Pierneef ever sold was one which represented Meintjeskop, entitled 'n Blik op Meintjeskop (A view of Meintjeskop) (Cartwright 1969:3). He painted it in 1910 and sold it to the Pretoria art dealer, Emil Schweickerdt, from whom he acquired much of his art materials. Fifteen years later, when Pierneef married Mariane Schoep, Schweickerdt produced the little oil and gave it to them as a wedding present.

Pierneef was aware of the political situation in South Africa in 1909/10 and had read about the proposed construction of the Union Buildings on Meintjeskop. Like Anton van Wouw, his godfather and teacher, Pierneef did not support the Imperialist ideas of Botha and Smuts at that time, rejecting their politics and the idea of erecting such a building in Pretoria. In a lecture in Bloemfontein in September 1917, Pierneef clearly revealed his thoughts about the Union Buildings when he described them thus: 'Gee gn (sic) indruk van Unie nie, maar 'n totale verbrokkeling. 'n Simbool van onenigheid' ('Gives no impression of Union, but a total disintegration. A symbol of disunity') (National Archives Repository, Pretoria: A941, file 19. Lectures: 50. Undated personal notes of J.H. Pierneef). Pierneef saw the erection of the Union Buildings on Meintjeskop as the destruction of one of the distinctive old landmarks of Pretoria, and rejected its ideological implications. At the same time, in February 1910 he had already started with the first of his 32 drawings of houses and views of the town. In 1949 he explained his initial idea with these drawings, saying:

My idea at the time [1910] was to preserve for the citizens of this city, a record of the old Pretoria which was soon to disappear ... Knowing that these old houses would be condemned by the Municipality because of their thatched roofs and mud floors, I made sketches of them with the intention of presenting 

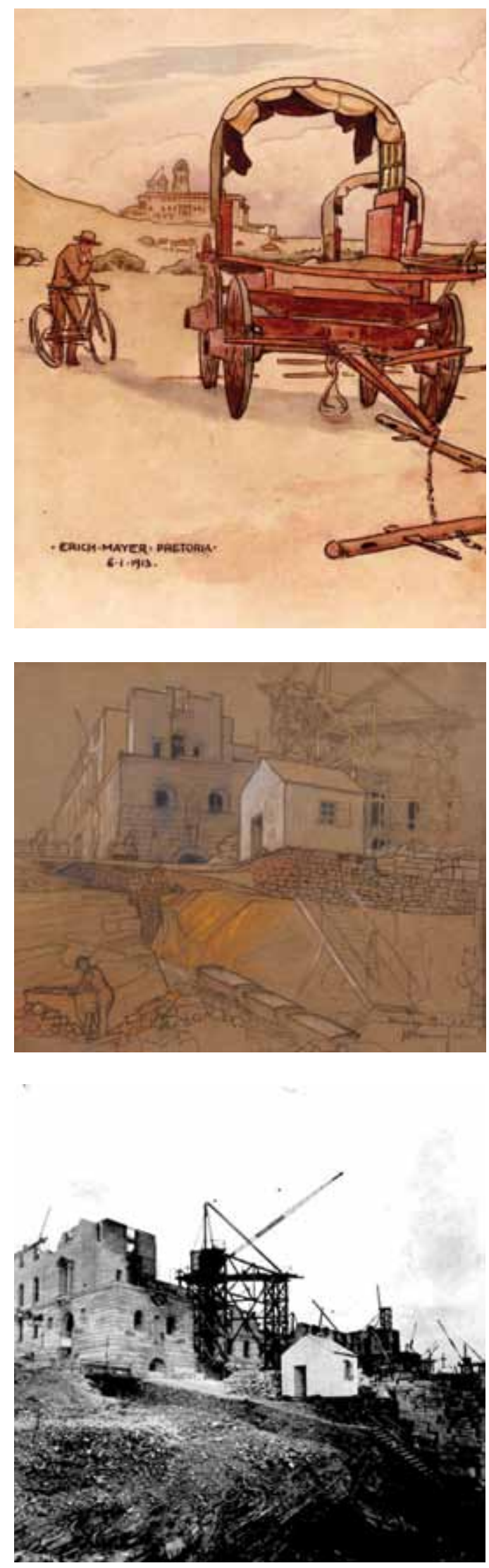

them to the Municipality at a later date. (Pretoria News 2 August 1949:1)

He felt that the then pro-British Municipality of Pretoria would destroy buildings which were considered vestiges of old Republican Pretoria, and therefore he started recording them. His involvement with the 'Individualists' at this time also allowed him regular dialogue with other artists and gave him the opportunity to exhibit his work with them. ${ }^{12}$

The Individualists also regularly accompanied Pierneef to Meintjeskop to draw and paint. In the Johannesburg Art Gallery there is a pastel drawing by Pierneef (dated 1910), which shows a seated Pieter Wenning drawing on the slope of Meintjeskop, with Pretoria in the distance. At the second exhibition of the Individualists in the Old Pretoria Town Hall on 29 July 1912, a number of artworks made at Meintjeskop by various members of this group were shown (Duffey 1986:5-10). ${ }^{13}$ At a slightly later date (in 1913 to be precise), Erich Mayer painted three watercolour drawings showing the Union Buildings under construction, ${ }^{14}$ without doubt having made these artworks while visiting the site with Pierneef. The earliest, dated 6 January 1913, shows two ox-wagons and a man with a bicycle on the western side of Meintjeskop (3). In the background one sees the Union Buildings under construction. The other is a watercolour of one of the towers of the Union Buildings being constructed and the third, entitled Union Buildings under construction, shows the almost completed buildings in the background with the houses of Arcadia and figures in the foreground (Welz 2008:30). ${ }^{15}$ The former two works are so close in style to Pierneef's

3 Erich Mayer, Uniegebou voor die voltooiing. Pen and watercolour, 17,2 x 13,7 cm. Signed I.b. Erich Mayer Pretoria 6-1-1913. University of Pretoria Art Collection. Since Mayer must have accompanied Pierneef to Meintjeskop at this time, the date on this drawing helps to date Pierneef's drawings of the same time.

4 J.H. Pierneef, Union Buildings. Pencil and crayon on greybrown paper, $26,2 \times 33,3 \mathrm{~cm}$. Signed r.b. J.H. Pierneef 1912. University of Pretoria Art Collection. The chaos on the building site is emphasised by Pierneef's excessive use of diagonal lines in the composition. Note the central workers' hut.

5 Photograph of the construction of the western wing of the Union Buildings (National Archives Repository, Pretoria: SAB 2022). The proportions of the stairway below the workers' hut and the ground floor windows of the Union Buidings are totally different to those in Pierneef's drawing. The destruction of the natural site is most evident in the foreground. 
drawings of that time, that they were originally thought to be by him and were catalogued as such by the University of Pretoria.

But above all it was Pierneef who really exploited the visual possibilities of Meintjeskop. At the first exhibition of the Individualists in the Old Pretoria Town Hall in November 1911, he exhibited three artworks representing Meintjeskop, namely Oil sketch near Pretoria no. 166, Veld (morning) no. 169 and an etching entitled View in Donkey Camp no. 174. ${ }^{16}$ Hereafter, Pierneef regularly exhibited paintings and drawings showing the hill or progress with the building. For instance, at his first solo exhibition at De Bussy bookshop in Van Erkom's building in Pretoria, on Friday 3 October 1913, Pierneef showed six artworks with Meintjeskop as theme (Boshoff 1936:17). ${ }^{17}$ These included two oils, both entitled Unie Paleis (Union Palace) nos. 17 and 19, an oil entitled Meintjes Kop, Avond (Meintjeskop, evening) no. 31, and three crayon drawings entitled Unie Paleis (Union Palace) nos. 45, 46 and 47. One cannot ignore Pierneef's sarcasm in referring to the Union Buildings as 'Union Palace'!

During 1912 and 1913, Pierneef was active in making drawings and paintings of the progress on Meintjeskop, about 20 of which have survived - there are 16 in the University of Pretoria Art Collection, ${ }^{18}$ two in the collection of MuseumAfrica in Johannesburg, and two in private collections. The earliest of Pierneef's views of the Union Buildings under construction were made early in 1912 and show the western wing being constructed (4). The earliest work, judging by the progress of the construction, is a crayon and pencil drawing in the University of Pretoria Art Collection, dated 1912. It shows the Buildings from a low angle, with the emphasis on a sun-lit worker's hut on the right. In the left foreground a worker loads a trolley and in the background behind the hut the gantries tower above the construction. Did Pierneef, in this drawing, want to emphasise the chaos on the building site and the way that the natural environment was being spoilt? When one compares the stairway on the right in this drawing, as well as the ground floor windows of the Union Buildings with those in a contemporary photograph of the same view, one clearly notices the liberties Pierneef took with the proportions (5). Already in this early work one also sees how clumsy he is at representing human figures and how he simplifies the scene with his emphasis on flat colour planes and decorative lines. He skilfully uses the grey-brown paper as background and only places blotches of rich colour here and there to accentuate things, such as the rich yellow-orange on the rocks above the trolley, the warm browns of the stone walls, and the sharp whites on the western wall of the Buildings and the worker's hut.

Another drawing in the University of Pretoria Art Collection can be dated to the same time (judging from the builders' progress) and shows the same view as the former work, only a bit further away to the south (6). This crayon drawing clearly reveals Pierneef's disgust at the chaos of the building operations on Meintjeskop. An oil sketch on board, also dated 1912 (probably based on a now lost drawing), shows the almost completed western wing from a point much further south, giving the Buildings in progress much monumentality. The lower two-thirds of this artwork show the churned-up hillside crowned by the massive building resembling a huge rectangular masonry block. ${ }^{19}$ This painting also shows how Pierneef dramatically simplified the scene by using large, flat areas of colour to model the massive Buildings and the rough terrain in the foreground. Pierneef knew that the harsh South African sunlight causes subtle colour nuances to disappear, so that only a few strong colour planes are left. He therefore moved away from the fragmented brushstrokes of the Impressionist approach and laid his colour on in broad colour planes. It is most interesting how the use of tiny silhouette figures in the foreground give dimension to the Buildings rising on the hilltop.

A more detailed oil sketch in MuseumAfrica, no. 58/1395, also dated 1912 and showing the Buildings at about the same time, represents the same view, but with more human figures in the foreground (7). This work may pre-date the painting previously discussed, as Pierneef must have realised the shortcomings in his human figures in the foreground and decided to redo the work without them. From this painting it is evident that the third level of the western wing has already been completed, as well as the two chimneys to the left and the right. From the dry grass in the foreground in a photograph at present in the National Archives in Pretoria (National Archives Repository, Pretoria: SAB photographs, no. 1716) showing the exact 

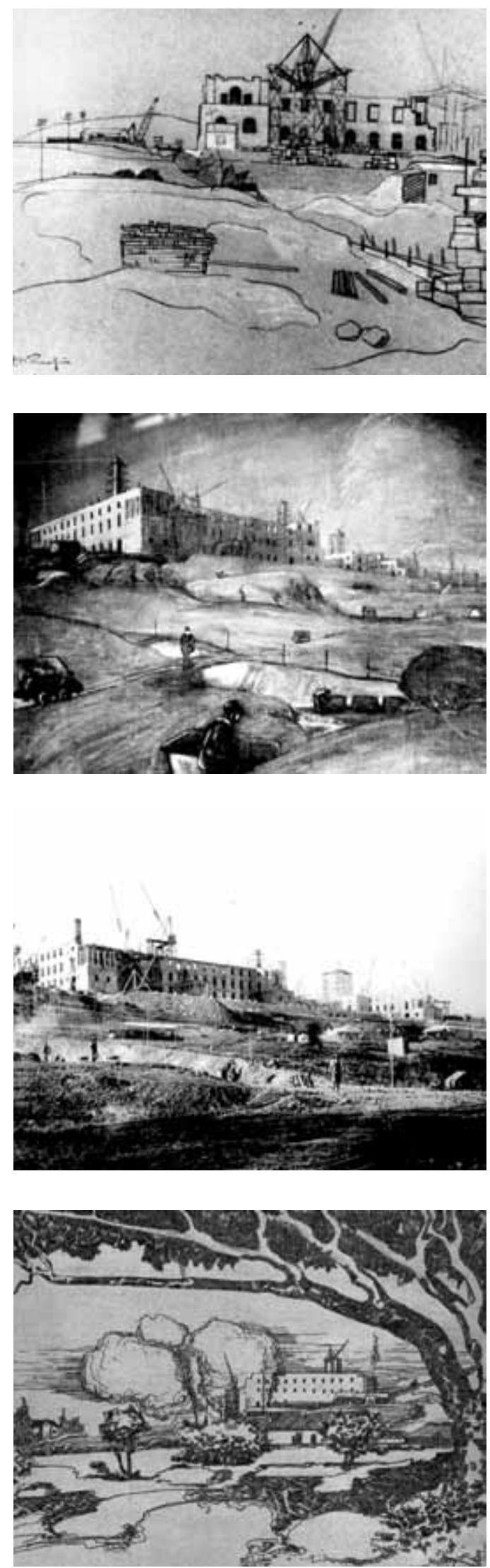

same view, one can assume it was taken in the winter of 1912 (8). Since the photograph slightly pre-dates the painting (the entablement of the left pavilion is not yet in place in the photograph), Pierneef must have painted this scene during June or July of 1912. As in the previously discussed work, Pierneef here emphasises the destruction of the environment with his portrayal of mounds of earth and trenches in the foreground.

A pen drawing of the Union Buildings under construction, from the opposite side of the hill and reproduced in De Volkstem of 23 August 1912, shows how Pierneef experimented with trees to balance his compositions at this time (9). This is also evident in a similar crayon drawing from the opposite end, entitled Arcadia - Union Buildings. Here again, the tree on the right stretches diagonally across the top of the drawing to frame the scene of houses and buildings under construction. The use of these trees allowed Pierneef to experiment with linear elements in his composition. Both these drawings typify the Buildings as an 'eye-sore' in the natural landscape. Another work from the same period as the previous two drawings (judging from the builders' progress), is the crayon drawing entitled Union Buildings from Arcadia. Although it gives a glimpse of the Buildings over the houses and trees in Arcadia, what especially catches the eye here is Pierneef's skilful use of soothing sinuous lines in the foreground, which reminds one of the work of Dutch Jugendstil artists such as Jan Toorop (1858-1928) and Henri van de Velde (1863-1957).

Two of the most stylistically revealing works in this series of drawings and paintings

6 J.H. Pierneef, Union Buildings under construction. Pencil and crayon on grey-brown paper, $27 \times 34,9 \mathrm{~cm}$. Signed I.b. J.H. Pierneef. University of Pretoria Art Collection. Construction on the Buildings indicates that this work was made at the same time as the one in Figure 4. The way in which Pierneef represents things chaotically strewn across the picture plane, clearly shows his disgust at the chaos of the building operations on Meintjeskop.

7 J.H. Pierneef, Union Buildings under construction. Oil on cardboard, $21 \times 26 \mathrm{~cm}$. Signed r.b. J.H. Pierneef 1912. MuseumAfrica, Johannesburg 58/1395.

8 Photograph of the construction of the Union Buildings (National Archives, Repository, Pretoria: SAB 1716). This photograph was made days before Pierneef made the painting in Figure 7. The dry grass in the foreground indicates that it was the winter of June 1912.

9 J.H. Pierneef, Union Buildings under construction. Pen and ink on paper, $13 \times 19,5 \mathrm{~cm}$. Signed I.b. J.H. Pierneef (From De Volkstem 23.8.1912). Note how the tree on the right frames the cloud covering the Union Buildings in progress. 
in the University of Pretoria Art Collection, are the pencil and crayon drawing and its eventual watercolour showing the back of the Union Buildings under construction (10 and 11). Fortunately, there is also a photograph of this exact view (National Archives Repository, Pretoria: SAB photographs, no. 1695). Pierneef's initial crayon drawing shows the back of the western wing with the basement and two floors completed. Above the main entrance there is a large crane and in front is a gangplank on which there are figures with wheelbarrows. In the final watercolour much has been simplified and the human figures have been emphasised to accentuate the angle of the gangplank. When one compares Pierneef's artworks with the old photograph of the scene, one immediately notices the mistakes in the proportions, not only of the gangplank in relation to the building behind it, but also of the windows, main entrance and cranes. Here one realises that Pierneef's aim is not to capture the scene, but rather to use its components to create a geometrically pleasing composition and to emphasise the chaos taking place on Meintjeskop at the time.

Pierneef's documentation of the construction stressed all aspects of the disappearance of the old. In his numerous drawings he shows that Meintjeskop, as the people of Pretoria knew it, would be changed forever, and with it was to come a new era of mechanisation. A crayon drawing dated to about mid-1912, judging from the progress on the Buildings in the background, shows one of the three large steam-driven cranes used in the construction (12). ${ }^{20}$ Here, the main emphasis is on the chaotic stacks of Portland stone, floor tiles, heaps of sand and the polluting steam crane on the right. The bright greens in the left foreground contrast well with the orange-

10 J.H. Pierneef, Union Buildings. Pencil and crayon on brown-grey paper, $27 \times 34,6 \mathrm{~cm}$. Stamped r.b. J.H. Pierneef. University of Pretoria Art Collection.

11 J.H. Pierneef, Union Buildings. Charcoal and watercolour on cream paper, 46 × $60 \mathrm{~cm}$. Signed r.b. Pierneef, inscribed I.b. Unie Gebouw 1912. University of Pretoria Art Collection.

12 J.H. Pierneef, Union Buildings. Crayon and pencil on paper, $26,5 \times 34,1 \mathrm{~cm}$. Signed I.b. J.H. Pierneef 1912, inscribed r.b. Union Buildings. University of Pretoria Art Collection. The main emphasis is on the chaotic stacks of Portland stone, floor tiles, heaps of sand and the polluting steam crane on the right.

13 J.H. Pierneef, Unie Paleis Agter. Oil on board, 27,6 x 34,1 cm. Signed I.b. Pierneef 1912. University of Pretoria Art Collection. Construction indicates that this painting dates to the end of 1912 .
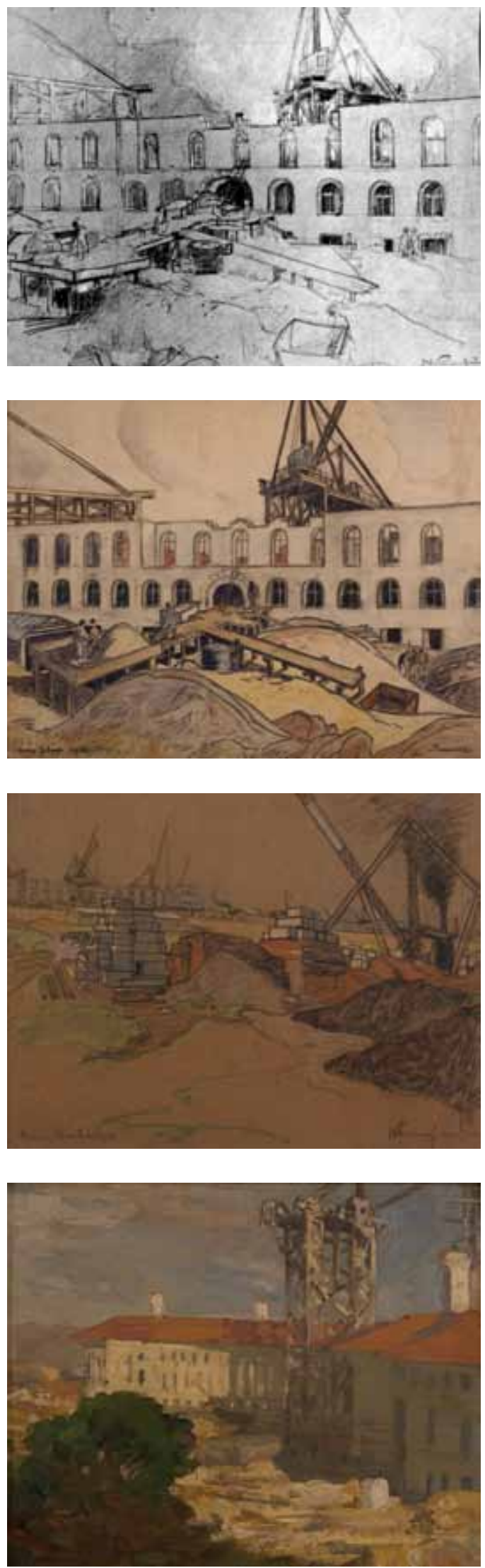

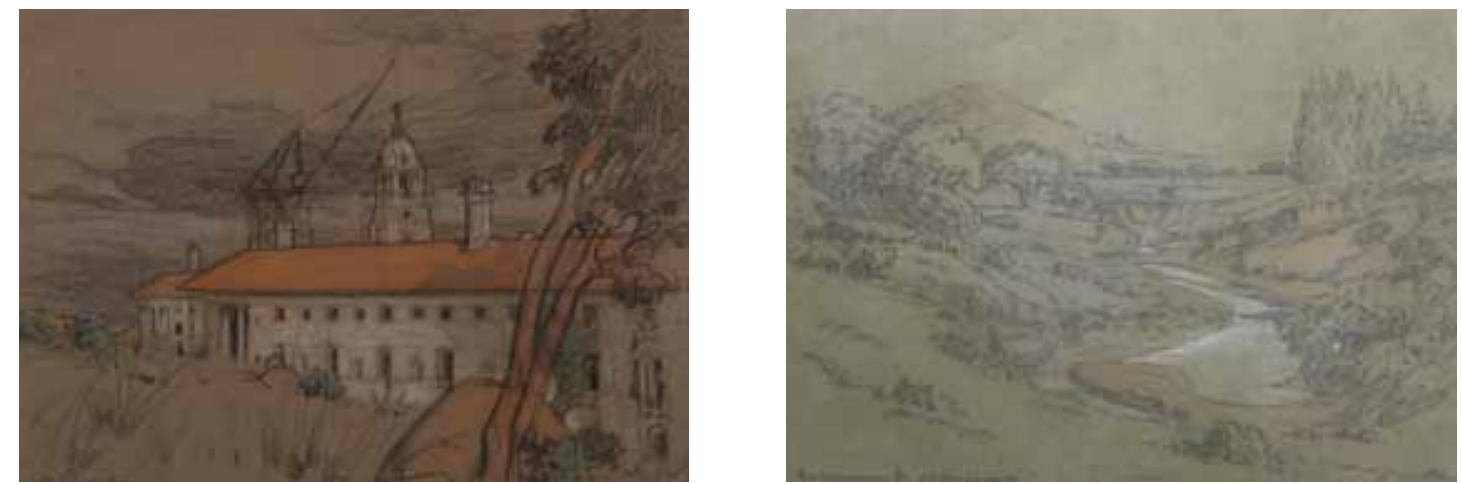

14 J.H. Pierneef, Uniegebou in Aanbou. Charcoal and crayon on grey paper, 25,3 x 35,4 cm. Stamped I.b. Pierneef. University of Pretoria Art Collection. The placing of the bronze Atlas figure on the Western tower, recorded in this drawing, dates it to the middle of 1913.

15 J.H. Pierneef, Apies River at Van der Hove's Drift. Crayon on grey paper, $26,5 \times 36 \mathrm{~cm}$. Signed r.b. Pierneef 1913. Pretoria Art Museum. Although the Union Buildings were already completed when this drawing was made, they are not represented on the southern slope of Meintjeskop.

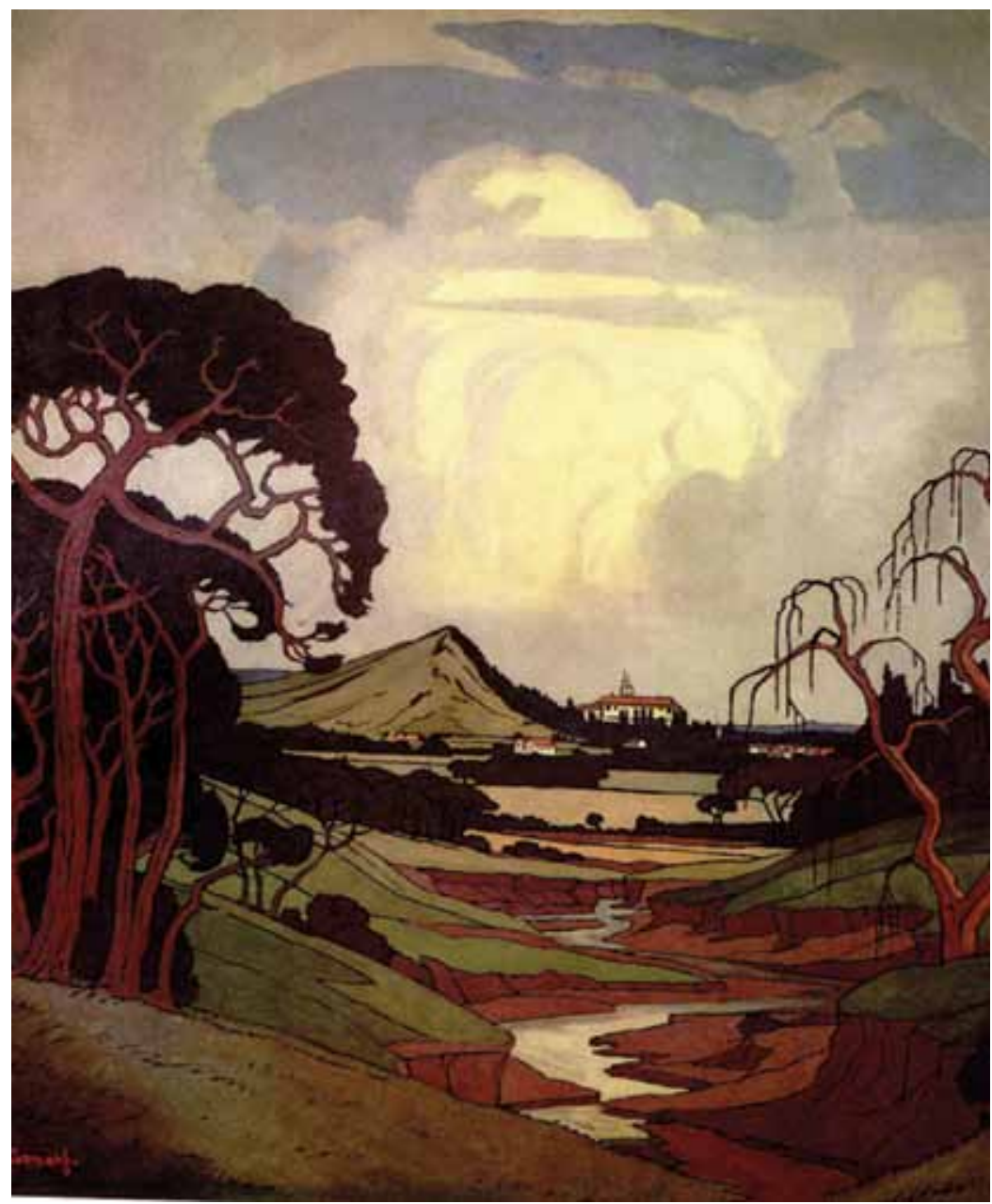

16 J.H. Pierneef, Apiesrivier, Pretoria. Oil on canvas on panel, 140 x 126,5 cm. Signed I.b. Pierneef. Rupert Collection, Graaff Reinet. In this station panel the Union Buildings are the focal point of an imaginary circle created by the trees and clouds. Although these Buildings are the most significant landmark in the painting, the title rather refers to the Apies River in the foreground. 
browns of the tiles. The white highlights on the roof of the shed in the middle background and the stacks of stones create an interesting decorative pattern across the breadth of the drawing, and show how the artist solves the problem of representing the harsh Pretoria sunlight. Remarkable is the pencil drawing of the steam traction engine ${ }^{21}$ which, according to a photograph of 1912 in the National Archives in Pretoria, stood where the Louis Botha equestrian statue now stands.

Towards the end of 1912, Pierneef produced an unusual oil painting of the almostcompleted Buildings from behind (13). The red tile roofs had already been added and the right side of the canvas is dominated by a massive wooden gantry with cranes. ${ }^{22}$ Here the massive Buildings and construction tower dominate the scene. Very obvious is the impasto Impressionist technique of loose brushwork, the large colour planes with which Pierneef was experimenting at this time, and the inclusion of a small shrub/tree in the left foreground, to indicate what is left of the natural environment of Meintjeskop.

In the next drawing Pierneef made, nature has totally disappeared and all that is left are the sheds, cranes and towering Buildings in the background. The steam crane and a large shed on the right and the Union Buildings in the left background, showing the completed western tower, dates to early 1913, when Erich Mayer accompanied Pierneef to the site to draw. ${ }^{23}$ Pierneef's deft pencil strokes on the grey paper with white, brown, orange and green colour areas tastefully spread over the whole picture plane emphasise the fact that he was a skilful draughtsman who very carefully planned his compositions. Four of the last artworks, which Pierneef made at the construction site in early 1913, show the Buildings from the back, with construction taking place on the eastern tower. Three of these drawings are in the University of Pretoria Art Collection and the fourth, a watercolour, is in MuseumAfrica. ${ }^{24}$ The most impressive of these works is a crayon drawing of the back of the Buildings, with a completed western tower in the centre and a crane, to the left of the tower, placing the bronze Atlas figure on the tower (14). The right of the picture plane is filled with a large boulder and tree.

In the period from the completion of the Union Buildings (end of 1913) until about 1948 , Pierneef continually returned to represent Meintjeskop, and there are at least
29 artworks from this period which show one or other aspect of the hill. ${ }^{25}$ These artworks also appeared at all Pierneef's exhibitions after $1913 .{ }^{26}$ Shortly after his exhibition in Pretoria in March 1914, Jenny Leech wrote the following: 'The crayon drawings of the Union Buildings, of which there are several, are fine work. In them Mr Pierneef has selected very happily and the drawings should prove a revelation to those who have looked at the buildings with unseeing eyes' (Q. 1914:212).

In order to see how Pierneef disapproved of the Union Buildings on Meintjeskop and used the subject to developed his specific style, I have chosen five artworks from the almost 30 which he produced of this site between 1913 and 1948 . The first is the crayon drawing entitled Apiesrivier by Van der Hove's Drif (Apies River at Van der Hove's drift), which is dated 1913 and is in the Pretoria Art Museum (15). The drawing shows the Apies River flowing in a gully in the foreground, with Meintjeskop clearly visible in the left background. What is interesting is that Pierneef has removed the Union Buildings, as they must already have been completed when he made this drawing - this was how he knew Meintjeskop, and he deliberately removed the newly completed and politically unacceptable Buildings from the scene. To show that this was deliberate and not just one of his works in his series of scenes of old Pretoria, another oil painting in the Johannesburg Art Gallery, painted four years later and entitled Meintjeskop, Pretoria, 1917, must be mentioned. It conveys the same sentiments, showing the exact same view, also without the Union Buildings. The suppression of this historically most significant feature of the hill after 1913, in these works, clearly defines Pierneef's attitude toward these Buildings with their clear political message.

Another artwork, Landskap Meintjeskop (Landscape Meintjeskop) (1921), is a magnificent oil painting which also represents the site in the central background with trees in the foreground, but without the Union Buildings. Here the Apies River again winds in a gully from the foreground to the hill in the background. Impressive are the towering 'Pierneef' clouds in the background, the puzzling combination of dead and living trees in the foreground, and Meintjeskop without the Union Buildings in the distance. Are the trees in the foreground symbolic of Pierneef's views 
of the original intentions of these Buildings? This painting was purchased for the new library in Pretoria in 1922, and afterwards came into the possession of Dr M. te Water. ${ }^{27}$ It can clearly be seen in a photograph Alan Yates took of Pierneef's studio early in 1922.

The third artwork I have selected is the station panel entitled Apiesrivier, Pretoria (16). The scene is identical to the one selected for the 1913 and 1921 paintings: it shows the Apies River winding in a gully from the foreground to Meintjeskop in the background, where the Union Buildings are clearly placed at the focal point of an imaginary circle created by trees and clouds. The same view was used for his 1925 linocuts, entitled Uniegebou vanaf Prinshof, Pretoria (Union Buildings seen from Prinshof, Pretoria) and Uniegebou en doringboom (Union Buildings and thorn tree). Two preliminary pencil sketches for the station panel Apiesrivier, Pretoria, which are in the National Archives in Pretoria and dated November 1931, clearly show how Pierneef planned the composition of the station panel. The trees in the one sketch are similar to those in the painting he made for the new library, and the Apies River in the foreground and clouds in the background are similar to those in the final artwork. The other drawing shows a willow tree to the right and the same placing of the Union Buildings with Meintjeskop in the centre of the scene. It is significant that Pierneef titled the preliminary sketch Uniegebou Nov 1931 (Union Buildings Nov 1931) at the bottom of the drawing, yet this specific station panel is entitled Apies River, Pretoria. Although the panel represents the Union Buildings, as officially required, Pierneef again ignored the significance of these Buildings by giving the panel the title of 'a small and insignificant little stream hardly qualifying as a landmark' (Coetzee 1992:33). ${ }^{28}$

The fourth work is a very large decorative painting, with the Buildings diagonally across the picture plane, as viewed from the southwestern corner and framed between large trees and aloes (17). The painting , commissioned by the City Council of Pretoria for the Union Castle ship 'Pretoria Castle' in 1938, was exhibited in Pretoria in January 1939 (Rand Daily Mail 24 January 1939:1). In October 1975, Safmarine gave the painting back to the City Council of Pretoria and it was placed in the foyer of the Council Chamber in Munitoria. Since this large painting was a public commission, Pierneef had to produce a work which complied with the wishes of the selection committee, therefore he created a mainly decorative work.

The last work, entitled Apiesrivier, Pretoria met Meintjeskop agter (Apies River, Pretoria with Meintjeskop behind) was created in 1948 and is in the Pretoria Art Museum. This work, painted in the year that the Nationalist Government came to power, once more shows Meintjeskop without the politically unacceptable Union Buildings and is again titled after the insignificant Apies River. This oil shows the winding river running in a gully

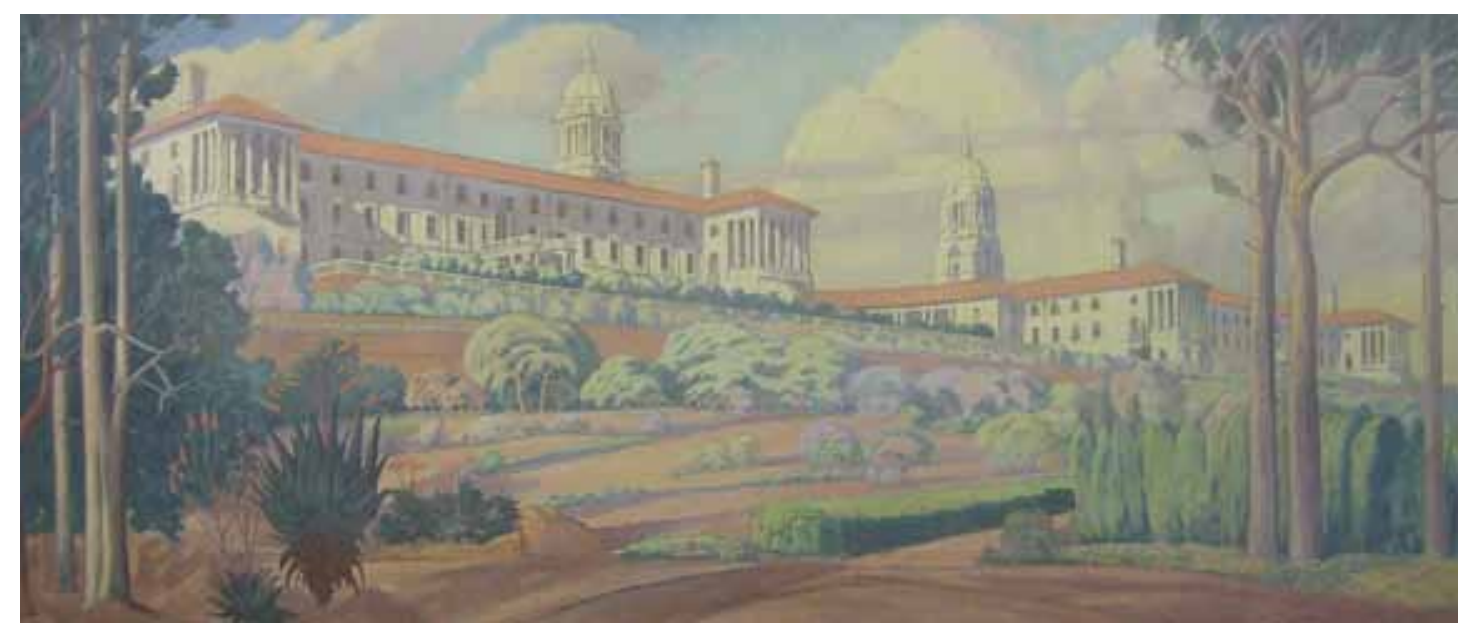

17 J.H. Pierneef, Union Buildings. Oil on hardboard, $100 \times 200 \mathrm{~cm}$. Signed r.b. Pierneef. Pretoria Art Museum. This painting was commissioned by the City Council of Pretoria for the Union Castle ship "Pretoria Castle" in 1938. Since it was a public commission, Pierneef had to comply with the wishes of the selection committee and therefore the work is mainly decorative. 
from the foreground to Meintjeskop in the background, with all the elements in the landscape (trees, bushes, ravines and the river) treated in a very decorative fashion. The use of subdued ochre colour planes is not typical, and characterises Pierneef's search for the monumental essence of this scene.

Through a study of all the artworks Pierneef produced with Meintjeskop and the Union Buildings as subject matter, one can clearly see his opposition to the Buildings being located on Meintjeskop, and also trace the development of his style from his early Art Nouveau roots through his Impressionist works to his very decorative and monumental final pieces. In every piece it is evident how he grapples with the problem of representing the light effects specific to Pretoria. He makes use of stylisation of line and decorative distortion of shape, sometimes adding elements such as trees, aloes and clouds, while removing others to heighten the dramatic effects of his landscapes. All his paintings of Meintjeskop and the Union Buildings reflect his ideological rejection of the ideals represented in these Buildings and emphasise his conservative Republican viewpoints. When we compare his artworks with old photographs, we notice how he departs from reality, creating fantasy pieces with reality only as a basis - this proves that his approach to the landscape was always more rational than visual. Yet, Pierneef was also always an artist with strong expressional abilities, instinctively placing elements in the picture plane so that they would be pleasing to the viewer. The finished works often show deliberate sensuality - especially in his use of distorted line. To heighten this effect all unnecessary detail had to be eliminated, and only the essence retained. Often in these Meintjeskop/Union Buildings paintings one encounters this type of approach, and for this reason this series of artworks has become, without doubt, one of the most important artistic experiments in Pierneef's entire oeuvre.

\section{Notes}

1 Letter Herbert Baker to Louis Botha (26 June 1909), National Archives Repository, Pretoria: PWD file 5269/1498. Two sketches and one perspective drawing dated 25 June 1909 are in this file.

2 Christenson (1996:5) expands on this when he states: 'Certainly, Baker was a logical choice for the job, considering his reputation for buildings such as Government House in Pretoria, but from the available evidence one must conclude that it was Baker's political connection to the Milner Kindergarten, and in turn to Jan Smuts, that ultimately secured him the commission.'

3 This was used as the internment camp for Boers during the Anglo-Boer War and Oerder was interned here. In MuseumAfrica there are three pencil drawings of the 'Donkiekamp' by Pierneef dated 1905: Nos. 62/1547, 62/1539 and 62/1540. (See Kennedy 1968:78.)

4 Pretoria Art Society Catalogue, 14 August 1908, Pierneef file, Art Archive of the University of Pretoria.

5 Eduard Salomon Frankfort was a Dutch Jewish painter who studied under August Allébé at the Rijksakademie van Beeldende Kunsten in Amsterdam. In 1905 he followed his sister to South Africa, where he toured and painted portraits. He came to Pretoria in 1906 and assisted Frans Oerder and A. Schild with the Rembrandt Tricentenary Festival and exhibition in the Old Pretoria Town Hall. (See De Volkstem 28 July1906:3.)

6 Wenning came to Pretoria in mid-1905 and must have met Pierneef shortly afterwards. The two artists went on drawing excursions together, as the Pierneef drawing of 1910, showing Wenning on Meintjeskop (now in the Johannesburg Art Gallery) proves. They were also both founder members of the artists' group the 'Individualists' in 1911.

7 The earliest correspondence between Pierneef and the Irish artist, George Smithard, who was living in Johannesburg, is dated November 1900. However, from 1909 until Smithard's death in 1919 they corresponded and visited each other regularly. Pierneef learnt the etching technique from Smithard.

8 Marcelle Piltan (Mrs W. Morley) was the driving force behind the establishment of the Individualists in May 1911 and often went to the construction site on Meintjeskop with Pierneef. They exhibited together in Pretoria from 25 November to 9 December 1922. Pierneef must have met her at the inaugural exhibition of the Pretoria Art Association in Tudor Chambers on 31 October 1904, where she exhibited six oils and his teacher, Frans Oerder, exhibited 23. (See Pretoria Art Association Catalogue, Pierneef file, Art Archive of the University of Pretoria.)

9 From February 1909 Pierneef corresponded regularly with the Cape artist, Pieter HugoNaudé.

10 Erich Mayer's contribution to Pierneef's use of San rock art in finding his personal approach to the landscape is discussed in my article in de arte 66 of September 2002, entitled 'Pierneef and San rock art', pp. 20-41. 
11 Smithard made Pierneef aware of his problems with proportion and perspective in a letter which he wrote to him in 1913: 'Re the etching you were good enough to send. Thought it is interesting in many aspects. I am afraid the drawing leaves something to be desired - the perspective requires a little attention.' (Letter G. Smithard - J.H. Pierneef 4.3.1913. Pierneef collection, Ferdinand Postma Library, Potchefstroom University (now North West University).)

12 The group called the Individualists, founded towards the middle of 1911, held their first exhibition together on 20 November 1911. It initially consisted of Marcelle Piltan (Mrs W. Morley), Miss Selina Harding, Madge Cook (Mrs B. Phillips Denham), Miss Nina Murray, Miss Sydney Stent, Mr G. Schild, Mr Pieter Wenning and Mr J.H. Pierneef. In 1912, Miss G. Anderson and Mr. J.L. Gartner were added and Fanie Eloff was invited to exhibit with them. (See Duffey 1986a:5-10.)

13 Pieter Wenning exhibited Donkiekamp no. 216, Mr. J.L. Gartner exhibited View from the Union Buildings no. 17, Nina Murray exhibited Pretoria from site of Government Buildings no. 109, Marcelle Piltan exhibited On top of a kopje, Pretoria no. 95 and Pierneef exhibited Near Apies river no. 196, an oil entitled Apies River near Hovesdrift, which showed Meintjeskop in the background, and Meintjeskop no. 31, about which a reporter of the Rand Daily Mail wrote: "Meintjes Kop" (31) is an ideal conception with a brilliant light effect on the hill upon which the Union Buildings now stand' (Rand Daily Mail 30 July 1912:6).

14 Two are in the University of Pretoria Art Collection and the third is in the Alec Wapnick Collection.

15 This work is in the collection of Alec Wapnick in Pretoria. The pencil and watercolour painting is signed and dated 1913 and measures 170 mm x 305 mm. Mr Wapnick owns another watercolour painting by Erich Mayer, entitled View of the Union Buildings from Hovesdrift, dated May 1916, which is very similar to Pierneef's views of Meintjeskop of this time.

16 Catalogue of the Individualists at the Town Hall, 20, 21, 22 November 1911: Pierneef works nos. 150-194, Pierneef File, Art Archive of the University of Pretoria.

17 Catalogue of the exhibition of J.H. Pierneef at De Bussy, 3 October 1913: Pastels nos. 1-14, Oils nos. 15-42 and Crayons nos. 43-47, Pierneef File, Art Archive of the University of Pretoria.

18 In the Pierneef inventory (p. iii) footnote 19 (April and July 1962) in the National Archives Repository, Pretoria: A941, file 13/2P there is the following comment: 'In die verband ook 'n aanbod om 17 werke wat verskillende stadia van die Uniegebou in aanbou voorstel, vir R400. Deur die Argief na die Departement van Openbare Werke verwys.' (In this regard also an offer of R400 for 17 works which represent different stages of the Union Buildings under construction. Referred to the Department of Public Works by the Archive). The works were then placed in the safe-keeping of the architect, Norman Eaton, as from 25 July 1962 and eventually Mrs May Pierneef donated them to the University of Pretoria after Professor F.G.E. Nilant had completed his book on Pierneef's linocuts. They were brought over to the University of Pretoria on 24 November 1978, where Professor Nilant and Mr A.E. Duffey received them.

19 In an undated lecture, Pierneef derogatively comments on the buildings as follows: 'Laat ons denk aan 'n massa lee vuurhoutjiesdosies versier met tallose pilaartjies en torings van sout en peper strooiers' ('Lets us think of a mass of match boxes decorated with many small pillars and towers like salt- and pepper-shakers'. (National Archives Repository, Pretoria: A941 file 19. Lectures: 50 . Undated personal notes of J.H. Pierneef.)

$20 \mathrm{~J} . \mathrm{H}$. Pierneef. Union Buildings. Crayon and pencil on paper, $265 \mathrm{~mm} \times 341 \mathrm{~mm}$. r.b. Union Buildings, I.b. J.H. Pierneef 1912. University of Pretoria Art Collection.

21 J.H. Pierneef. Steam Traction Engine, Union Buildings. Pencil and white crayon on greybrown paper, $271 \mathrm{~mm}$ x $346 \mathrm{~mm}$. r.b. stamped, J.H. Pierneef. University of Pretoria Art Collection.

22 The Pretoria News of 15 November 1912 notes that: 'During a storm last night a small gantry in front of the Union Buildings was struck by lightning and ignited.' This is confirmation that these gantries were wooden structures.

23 In the University of Pretoria Art Collection there are two watercolour paintings by Erich Mayer, which were made at exactly the same time that Pierneef also worked there. They are: E. Mayer, Union Buildings from the West. Watercolour, 172 mm x 137 mm. I.b. Erich Mayer. Pretoria. 6.1.1913. University of Pretoria Art Collection and E. Mayer, Union Buildings under construction. Watercolour, $247 \mathrm{~mm}$ x $356 \mathrm{~mm}$. I.b. Erich Mayer 6.1.1913. University of Pretoria Art Collection.

24 The four works are:

1. J.H. Pierneef, Union Buildings from the west. Charcoal and crayon on grey paper, $35,6 \mathrm{~cm} \times 25,1 \mathrm{~cm}$. Signed r.b. J.H. Pierneef 13. University of Pretoria Art Collection.

2. J.H. Pierneef. Union Buildings, Pretoria. Charcoal and crayon on grey paper, 25,3 $\mathrm{cm} \times 35,4 \mathrm{~cm}$. Signed I.b. J.H. Pierneef. University of Pretoria Art Collection. 
3. J.H. Pierneef. Union Buildings under construction. Pencil and crayon on grey paper, 39,6 cm x 29,6 cm. Signed I.b. J.H. Pierneef 1913. University of Pretoria Art Collection.

4. J.H. Pierneef. Union Buildings under construction. Watercolour, $185 \mathrm{~mm} x$ 153 mm. I.b. Pierneef. MuseumAfrica, Johannesburg 50/833.

25 The 29 artworks by Pierneef showing Meintjeskop after 1913 in chronological order are:

1. Pretoria - Panorama. Pastel on brown paper, $125 \mathrm{~mm}$ x $375 \mathrm{~mm}$. MuseumAfrica, 62/1530.

2. Apies River at Van der Hove's Drift. Crayon on paper, $265 \mathrm{~mm} \times 360 \mathrm{~mm}$. r.b. Pierneef 1913. Pretoria Art Museum.

3. Uniegebou. Oil on canvas, $330 \mathrm{~mm} \times 480$ mm. I.b. J.H. Pierneef 1917. Dr Victor Hesse.

4. Meintjeskop, Pretoria. Oil on canvas, $355 \mathrm{~mm}$ x 455. I.b. Pierneef 1917. Johannesburg Art Gallery.

5. Uniegebou, Pretoria. Pencil on paper, 150 mm x 350 mm. l.b. monogram "P", r.b. April 5 1919. National Archives Repository, Pretoria: A941.

6. Uniegebou, Pretoria. Red and black conte, $350 \mathrm{~mm}$ x $520 \mathrm{~mm}$. I.b. Pierneef 1920 . National Archives Repository, Pretoria: A941 no. 691.

7. Landskap Meintjeskop. Oil on board, 1140 $\mathrm{mm} \times 1070 \mathrm{~mm}$. I.b. Pierneef 1921. Dr C van Bergen, Pretoria.

8. Union Buildings from Van der Hove's Drift. Oil on board, $230 \mathrm{~mm} \times 340 \mathrm{~mm}$. I.b. Pierneef 1922. Prof M.S.B. Kritzinger, Pretoria.

9. Union Buildings from Van der Hove's Drift. Pen and ink, $100 \mathrm{~mm} \times 180 \mathrm{~mm}$. r.b. Pierneef, 1922. Cover for Pretoria Oost Eindschool 1897-1922.

10. Tentoonstelling/Exhibition. Charcoal on brown paper, $870 \mathrm{~mm} \times 605 \mathrm{~mm}$. r.t. 19P22. MuseumAfrica, Johannesburg $64 / 1120$.

11. Uniegebou vanaf Prinshof, Pretoria. Pen and ink, $280 \mathrm{~mm} \times 355 \mathrm{~mm}$. r.b. J.H.Pierneef 1923. MuseumAfrica, Johannesburg 62/1556.

12. Meintjeskop. Pencil on paper, $118 \mathrm{~mm} \times$ 205 mm. National Archives Repository, Pretoria: A941 no. 695.

13. Preliminary sketch for Meintjeskop, Pretoria. Pencil on paper, $118 \mathrm{~mm} x$ 205 mm. r.o. J.H. P. National Archives Repository, Pretoria: A941 no.700.

14. By die Waterpoel. Watercolour, $150 \mathrm{~mm}$ $x 210 \mathrm{~mm}$. J. Lion-Cachet. This is another preliminary sketch for the oil entitled Meintjeskop, Pretoria.

15. Meintjeskop Pretoria. Oil on canvas, 455 $\mathrm{mm} \times 605 \mathrm{~mm}$. r.b. J.H. Pierneef 1925. Mr $\&$ Mrs Beckerling, Cape Town. This is one of Pierneef's few oils that contain human figures.

16. Union Buildings from Arcadia. Pencil on paper, $80 \mathrm{~mm} \times 300 \mathrm{~mm}$. r.b. J.H.P. National Archives Repository, Pretoria: A941.

17. Uniegebou. Linocut, $80 \mathrm{~mm} \times 125 \mathrm{~mm}$. I.b. "P" on lino/ J.H. Pierneef impr. R.b. title. Pretoria Art Museum (Nilant no. 38).

18. Uniegebou vanaf Prinshof, Pretoria. Linocut, $283 \mathrm{~mm} \times 267 \mathrm{~mm}$. I.b. J.H. Pierneef. Schweickerdt Collection, Pretoria. Tracing paper drawing of this linocut in National Archives Repository, Pretoria: A941 no. 1937.

19. Uniegebou en Doringboom. Linocut, 150 $\mathrm{mm} \times 225 \mathrm{~mm}$. I.b. J.H. Pierneef. Pretoria Art Museum 65/137 (Nilant no. 37). A tracing paper drawing of this linocut in reverse is in the National Archives Repository, Pretoria: A 941 no. 722.

20. Uniegebou. Pencil on paper, $230 \mathrm{~mm}$ x $185 \mathrm{~mm}$. I.b. Pierneef 1931. National Cultural History Museum, Pretoria.

21. Preliminary sketch for Apiesrivier, Pretoria. Pencil on paper, $240 \mathrm{~mm} \times 200 \mathrm{~mm}$. r.b. stamped J.H.P., I.b. Nov. 1931. National Archives Repository, Pretoria: A941.

22. Preliminary sketch for Apiesrivier, Pretoria. Pencil on paper, $210 \mathrm{~mm} \times 185 \mathrm{~mm}$. r.b. J.H.Pierneef. I.b. Uniegebou, Nov. 1931. Miss J. van Tilburg.

23. The Station panel Apiesrivier, Pretoria. Oil on canvas on panel, $1400 \mathrm{~mm} \times 1265$ mm. I.b. Pierneef. Rupert Museum, GraaffReinet.

24. Uniegebou van die Sykant. Pencil on grey paper, $280 \mathrm{~mm} \times 400 \mathrm{~mm}$. r.b. stamped J.H. Pierneef. National Archives Repository, Pretoria: A941 no. 1932.

25. Union Buildings from behind. Crayon on brown paper, $520 \mathrm{~mm} \times 365 \mathrm{~mm}$. u.s. National Archives Repository, Pretoria: A941 no. 727.

26. Uniegebou van Sykant. Crayon on brown paper, $80 \mathrm{~mm}$ x 300mm. r.b. stamped J.H.P. National Archives Repository, Pretoria: A941 no. 724.

27. Preliminary sketch of Union Buildings. Pencil on paper, $320 \mathrm{~mm} \times 710 \mathrm{~mm}$. u.s. Divided into 21 blocks. National Archives Repository, Pretoria: A941 no. 698.

28. Union Buildings. Oil on hardboard, 1000 $\mathrm{mm} \times 2000 \mathrm{~mm}$. Pretoria Art Museum. Painted on commission for the Pretoria 
City Council in 1938, it was donated in 1939 to the ship "Pretoria Castle" (S.A. Oranje), but on 12 April 1976 Safmarine gave the painting back to the City Council of Pretoria. It was then placed in the foyer of the Council Chamber in Munitoria, but is at present in the Pretoria Art Museum.

29. Apiesrivier, Pretoria met Meintjeskop agter. Oil on panel, $500 \mathrm{~mm} \times 650 \mathrm{~mm}$. I.b. J.H. Pierneef 1948. Pretoria Art Museum.

26 Pierneef exhibitions after 1913, where Union Buildings and Meintjeskop artworks appeared, were:

1. Catalogue of the J.H. Pierneef/ Fanie Eloff Exhibition, 12 October 1917: No. 10 Union Buildings (oil) and No. 17 Impression Meintjeskop (oil).

2. Catalogue of the J.H. Pierneef/ Major C. FitzRoy Exhibition, November 1918: Nos. 54, 61 and 62 Union Buildings (watercolours) and No. 79 Union Buildings (crayon drawing).

3. Catalogue of J.H. Pierneef Exhibition, Bloemfontein, 8-15 November 1919: No. 51 Uniegebou skets (oil).

4. Catalogue of J.H. Pierneef Exhibition, Stellenbosch, 3-13 April 1921: No. 8 Meintjeskop.

5. Catalogue of J.H. Pierneef Exhibition, Lezards Sale Rooms, Johannesburg, 5 May 1921: No. 33 Union Buildings (watercolour), No. 46 Union Buildings (woodcut) and No. 41 Meintjeskop (woodcut).

6. Catalogue of J.H. Pierneef Exhibition, Ashbeys, Cape Town, 18 October 1921: No. 6 Meintjeskop (woodcut).

7. Catalogue of J.H. Pierneef Exhibition, Pretoria, 5 May 1925: No. 32 Union Buildings (watercolour), No. 40 Meintjeskop (woodcut) and No. 45 Union Buildings (woodcut).

8. Catalogue of J.H. Pierneef Exhibition, Amsterdam, 10 October 1925: No. 5 Meintjeskop, No. 32. Uniegebouw and No. 48 Uniegebouw.

9. In the "Inventory: works of J.H. Pierneef remaining at "Langeni", Pretoria October 1957', the following Union Buildings artworks were recorded:

No. 32 Unie Gebou. Watercolour, $475 \mathrm{~mm}$ x $615 \mathrm{~mm}$ I.b. Pierneef.

No. 84 Uniegebou (early stages of construction) Oil on canvas, $255 \mathrm{~mm} x$ $335 \mathrm{~mm}$. I.b. J.H. Pierneef. This is proof that Pierneef did not sell these artworks, but kept them.

27 In the Erich Mayer File in the Art Archive of the University of Pretoria there is a significant letter from him to Mrs Roosegaarde-Bischoff, no. 0189 , with regard to this painting. It states: 'Although I am now assured that you will do your best on Pierneef's behalf, I cannot dispel some fears that others who will take up this delicate matter, may by-and-bye introduce some misunderstanding, unless some essential points are constantly kept before them.

1. There is no question of Pierneef offering any of his works to the Public Library in Pretoria or to people interested in this library, nor that he is looking out for any orders for fresh work to be done with his brush, but: His health is still so impaired that he cannot do much strenuous or underpaid work for some time to come, and that by straining himself too much in order to earn a scanty living, the bad state of his health and thereby the bad financial position in which he is at present by consequence of his long involuntary rest, may be aggravated instead of relieved.

2. That the essential point I have laid before you is that this situation which should interest everyone who is honestly interested in the origination of a truly South African Art, could only be relieved by placing at the artist's disposal a considerable sum, without expecting from him an immediate exertion in a fresh creative effort.

3. That every true artist, and especially an overstrained or ailing artist, is, and must needs be, a highly sensitive being, and that such an action of help as the one in case, ought to be treated in the most delicate way.

4. That therefore, in order to take away the weight a greater monetary gift might place on his mind, I suggested, that the friends of Pierneef's noble art, who mean to help him, might in return of their free gift (of $£ 150$ or at least £200) take over, and present to the new library, a finished masterpiece of his, which is standing in his studio.'

28 Coetzee (1992:33) correctly notes that Pierneef had political motives for calling the panel Apies River, Pretoria instead of Union Buildings, which is the most historical significant feature of the scene. What Coetzee does not say is that all along there was no change in Pierneef's attitude toward the Buildings and their symbolism - he always detested what they stood for.

\section{References}

Andrews, T.E. 1962. The Union Buildings on Meintjeskop. Pretoriana (Aug-Dec):32.

Baker, H. 1944. Architecture and personalities. London: Oxford University Press.

Boshoff, S.P.E. 1936. Pierneef, lewensfeite werp lig op sy kuns. Die Huisgenoot 20 November 1936:17. 
Bouman, A.C. 1926. De Zuid-Afrikaanse schilder J.H. Pierneef. Elsevier's Maandschrift 36(LXXI): 1-9.

Cartwright, A.P. 1969. Once a tobacconist, Hendrik always longed to paint. The Star 11 October 1969:3.

Catalogue of the 'Individualists' at the Town Hall, 20, 21, 22 November 1911: Pierneef File, Art Archive of the University of Pretoria.

Catalogue of the exhibition of J.H. Pierneef at De Bussy, 3 October 1913: Pierneef File, Art Archive of the University of Pretoria.

Christenson, E. 1996. Herbert Baker, the Union Buildings and the politics of architectural patronage. S.A. Journal of Art and Architectural History 6(1-4):1-9.

Coetzee, N.J. 1992. Pierneef, land and landscape: The Johannesburg station panels in context. Johannesburg: CBM Publishing.

Duffey, A.E.1986. Pierneef die rasionele skilder. Museum Memo 14(3):8-10. .1986a. Pierneef and the Individualists. Historia 31(1):5-10. 2002. Pierneef and San rock art. de arte 66:20-41. 2006. Erich Mayer, Walter Battiss and San rock art. de arte 74:20-36.

Engelbrecht, S.P. et al., eds. 1955. Pretoria 1855-1955. History of Pretoria. Pretoria: City Council of Pretoria.

Greig, D. 1970. Herbert Baker in South Africa. Cape Town: Howard Timmins.

Hartdegen, P. 1988. Our building heritage: An illustrated history. Johannesburg: Ryell's Publishing.

Het Rembrandt feest te Pretoria. De Volkstem 28 July 1906:3.

Keath, M. 1990. Herbert Baker: Architecture and idealism. Gibraltar: Ashanti Publishing.

Kennedy, R.F. 1968. Catalogue of pictures in the Africana Museum, Volume 4: M-S. Johannesburg: Africana Museum.

Letter G. Smithard - J.H. Pierneef 4.3.1913. Pierneef collection, Ferdinand Postma Library, Potchefstroom University (now North-West University).

Marais, J.F. \& A. Hendriks. 1964. Commemorative booklet printed on the occasion of the Pierneef Festival. Johannesburg: Egon Guenther and Adler Fielding Galleries.

Meiring, A.L. 1955. Die Uniegebou. Pretoriana 32/33:115-117.

National Archives Repository, Pretoria: P.W.D. file $13 / 5267$ . PWD file 5269/1498.

. A941, file 13/2P. . A941, file 19, Lectures: 50. Undated personal notes of J.H. Pierneef. SAB photographs, no. 1695. . SAB photographs, no. 1716.
Nel, P.G., ed. 1990. J.H. Pierneef: His life and his work. Cape Town: Perskor.

Nilant, F.E.G. 1974. Die hout- en linosneë van J.H. Pierneef. Kaapstad: A.A. Balkema.

Op besoek by Pierneef. 1912. Die Volkstem 23 Augustus.

Picture for new liner. 1939. Rand Daily Mail 24 January: 1 .

Pierneef mymer oor die hoedanighede van die ware kunstenaar. 1944. Die Transvaler 9 Desember:3.

Pierneef trying to trace old city families. 1949. Pretoria News 2 August:3.

Potgieter, D.J., ed. 1972. Standard encyclopaedia of southern Africa, Volume 11:61-62. Cape Town: Nasionale Boekhandel Bpk.

Pretoria Art Association Catalogue, Pierneef file, Art Archive of the University of Pretoria.

Pretoria Art Society Catalogue, 14 August 1908 , Pierneef file, Art Archive of the University of Pretoria.

Pretorius, E.E. 1990. Biography of Jacob Hendrik Pierneef. In J.H. Pierneef: His life and his work, ed. P.G. Nel, 27-109. Cape Town: Perskor. . 1990a. Pierneef and the artists of his time. In J.H. Pierneef: His life and his work, ed. P.G. Nel, 158-168. Cape Town: Perskor.

Punt, W.H.J. 1955. Die oord-, wyk- en straatname van Pretoria. In Pretoria 1855-1955: History of the City of Pretoria, ed. S.P. Engelbrecht, 244-268. Pretoria: City Council of Pretoria.

$Q$ (Miss J. Leech). 1914. Mr Pierneef's exhibition of pictures in Pretoria. The South African Bookman 10 (March):212.

Radford, D. 1988. Baker, Lutyens, and the Union Buildings. South African Journal of Cultural and Art History 2(1):62-69.

Renken, C.R.E. 1989. Union Buildings: 75 years. Pretoria: Bureau for Information.

Solomon, J.M. 1910. The Union Buildings and their architects. The State IV(1) (July):3-18.

Stent, V. 1912. The Individualists at the Town Hall. Pretoria News 30 July.

The Individualists. 1912. Rand Daily Mail 30 July:6.

The Union Buildings, Pretoria, South Africa. 1913. The Builder 3 October:345-346.

'n Transvaalse skilder: Pierneef en sy werk. 1917. Die Huisgenoot 1(11) (Maart):271.

Van der Waal-Braaksma, G. 1990. Pierneef - the artist. In J.H. Pierneef: His life and his work, ed. P.G. Nel, 116-157. Cape Town: Perskor.

Welz, S. 2008. Pretoria views from the past: $A$ selection of paintings and linocuts from the Alec Wapnick Collection. Pretoria: City property.

Z. 1915. Mr Pierneef's exhibition - a private view. Pretoria News 16 November:3. 